\title{
A survey on Cuckoo Search Algorithm for Optimization Problems
}

\author{
Yogendra Kumar \\ Ph.D. Scholar \\ NIT Hamirpur, H.P. (India) \\ Himanshu Verma \\ Ph.D. Scholar \\ NIT Hamirpur, H.P. (India)
}

\section{Abstract}

Cuckoo search algorithm is one the efficient algorithms in solving global optimization problems. This paper provides an overview of cuckoo search algorithm as well as its latest applications and developments in the last decade. Regarding cuckoo search algorithm many papers have been published in the last few years and the relevant literature has also been expanded significantly. This Paper summarizes briefly the majority of the literature of last decade from 2009 to 2019 about cuckoo search, published in peer-reviewed journals and conferences. The references can be used as a basis for further research in cuckoo search as it is systematically classified into appropriate categories.

\section{Introduction}

Computational intelligence and optimization are the active area which are growing quite rapidly and expanding their literature. For most applications, resources, money and time are always limited and therefore, it is one of the most important requirement to design optimal solutions to maximize their utilization. However, it is really hard 
to find optimal solutions of many optimization problems in the real world. There are some problems which are NP-Hard problem such as travelling salesman problem.

In general, these NP-hard problems have no efficient algorithms. In most of the cases, the only alternative for Np-Hard problems is to apply heuristic or metaheuristics methods. The solutions of heuristic methods are based on trial and error, while metaheuristic methods are based on higher level heuristic methods that utilize selection and information of the solutions to help in the search process. Though the optimality is not always found or reachable, still optimization are the techniques and tools to solve such problems having the aim to find the optimal solutions in the real-world systems.

In the last few decades, nature-inspired metaheuristic algorithms have achieved huge popularity in optimization, data mining, computational intelligence, machine learning artificial intelligence and other engineering applications. The formulation of optimization problems can be framed in many ways such as, the least-squares is a specific case of maximum-likelihood formulations in the commonly used methods. A nonlinear optimization problem is formulated as

$$
\text { minimize } \quad f_{m}(x),(m=1,2, \ldots, M)
$$

subject to the constraints

$$
\begin{gathered}
h_{j}(x)=0, j=1,2, \ldots, J \\
g_{k}(x) \leq 0, k=1,2, \ldots, K
\end{gathered}
$$

where $f_{m}, h_{i}$ and $q_{k}$ are the functions, which is nonlinear and the design variable or design vector $x=\left(x 1, x 2, \ldots, x_{d}\right)$ ca be discrete, continues or mixed in d-dimensional space. The functions $f m$ are called cost functions or objective functions and if $\mathrm{M} i$ 1 , then optimization problem is called multicriteria or multiobjective problem.

There are so many optimization problems are available and corresponding so many optimization algorithms also available in the literature but there is not a single algorithm is suitable for all optimization problems. Even so, researchers still forms the major efforts in the search for efficient algorithm. Metaheuristic algorithms have attracted the attention of researcher now a days, in the area optimization. Metaheuristic algorithms are often nature-inspired and have many benefits over conventional algorithms.

Cuckoo Search is an evolutionary and Metaheuristic optimization algorithm which is developed by Xin-She Yang and Suash Deb in 2009 [1]. The theory of this optimization search algorithm is inspired by the bird species, called cuckoo. Cuckoo are the birds which make the beautiful sound and has a aggressive reproduction system, 
by reproduction strategy mature cuckoos lay their eggs in the nests of other species or host, which is known as obligate blood parasitism [6]. In addition, cuckoo search algorithm is enhanced by the so-called Levy flights.

\section{Biological inspiration}

- Eggs in nests : Set of solutions of optimization problem

- Cuckoo egg : New solution of optimization problem.

- Less fit solutions will be replaced by better and new solutions.

- After leaving nest, Cuckoos change position with Levy flights.

\section{Cuckoo Search Methodology}

Cuckoo Search algorithm has attracted the attention of researchers due to its promising efficiency in real-world applications and solving many optimization problems. For describing the standard Cuckoo Search, the following three idealized rules [5] are used:

- At a time, one egg is laid by each cuckoo, and it is dumped in a randomly chosen nest;

- The best nests with high-quality eggs will be carried over to the next generations;

- The number of available host nests are fixed, and the egg laid by a cuckoo is discovered by the host bird with a probability $p a \leq(0,1)$. In this case, the host bird can either get rid of the egg, or simply abandon the nest and build a completely new nest.

Based on the above three standards, the basic steps of the Cuckoo Search can be summarized as the pseudo code shown in fig 2. [1] and following fig 1 shows a flowchart of the Cuckoo search Algorithm. 


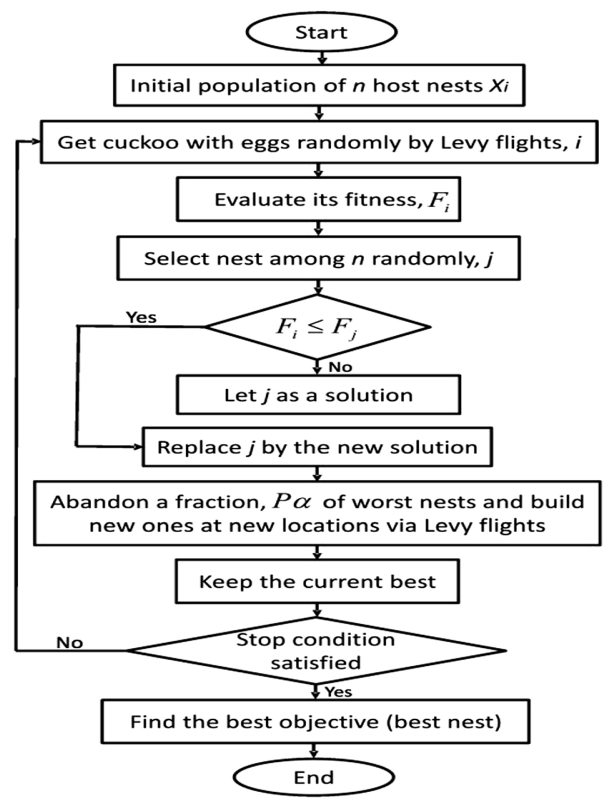

Figure 1: Flowchart of Cuckoo Search Algorithm

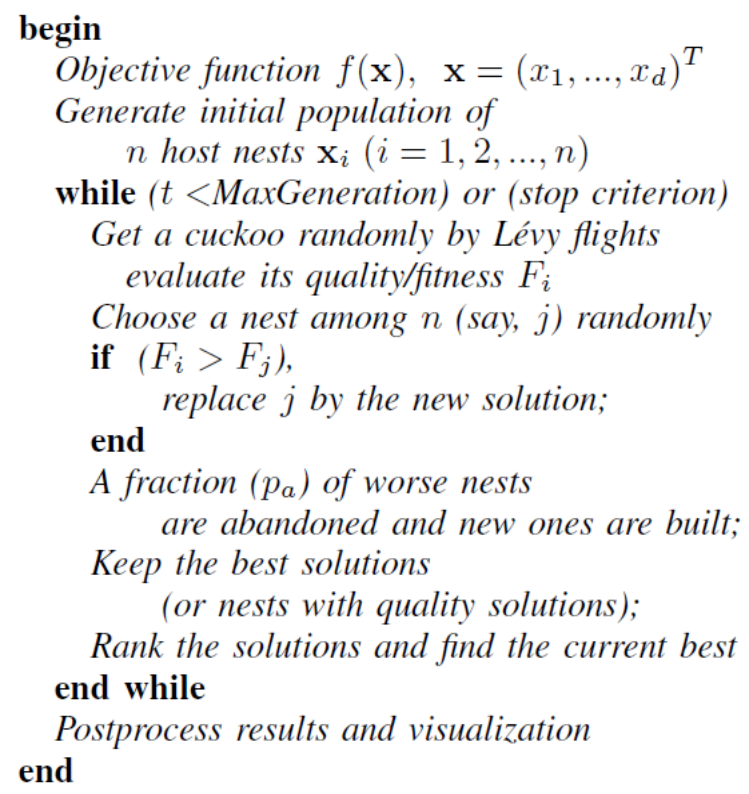

Figure 2: Pseudo code of the Cuckoo Search 


\section{Literature Survey}

Since the first appearance of cuckoo search algorithm in 2009, there are so many variants of the cuckoo search algorithm have been proposed and developed by many researchers in different domains. The major variants are shown in fig. 3 and different applications and proposed work in different domains of last decade from 2009 to 2019 are explained as following and summarized in table 1, table 2, table 3 and table 4 .

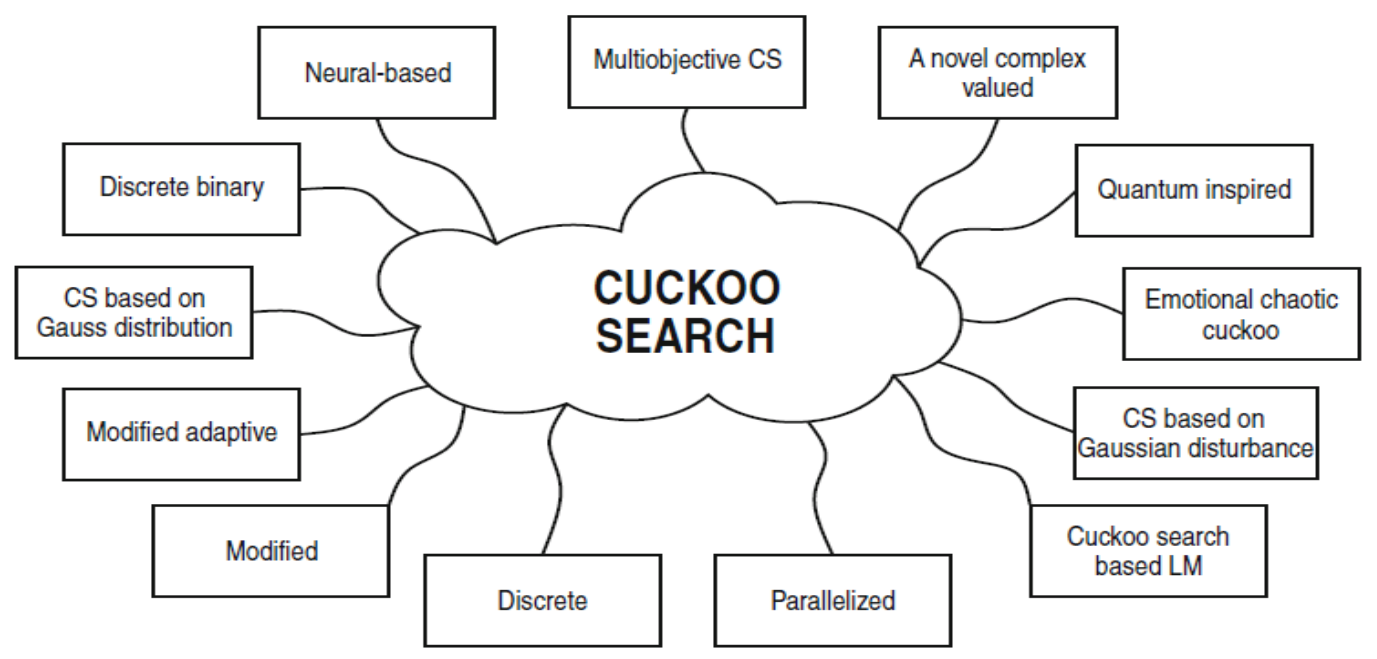

Figure 3: Variant of cuckoo search

In production and real life, There are the problems which require optimization for multiple conflicting points simultaneously, are called Multi-objective optimization problem. Xingjuan Cai et al. [7] proposed a optimization method for kind of problems based on Multi-objective cuckoo search algorithm.

Echo state network is neural network which solves the complexities in Recurrent neural networks. Abubakar Bala et al. 8] proposed an echo state network, in which cuckoo optimize search algorithm was used for right parameter and topology. It was observed that cuckoo search algorithm performed better than classical echo state network, particle swarm optimization and binary particle. The propose method was tested for degradation prediction on turbofan engine using.

For faster and better services in cloud computing effective and optimize methods are require for task scheduling. Prem Jacob et al. [9] proposed an optimized algorithm to solve the issues of scheduling task in cloud computing based on a hybrid 
approach by the combining Particle swarm optimization and Cuckoo search algorithm. The proposed method reduced the cost factors as user cost and performance cost.

Liang Chen et al. [10] proposed an Dimension by dimension enhanced cuckoo search algorithm.To provide the optimal solution, the proposed algorithm takes the advantage of all the dimensions by observing the dimensions which are bringing and updating the information.

Tejeswara Rao et al. [11] used cuckoo optimization search algorithm and fuzzy logic to reduce the power losses by placing Static VAR Compensator at optimal and efficient location.

In Grid Computing Transaction Scheduling is known as the NP hard Problem. Dharmendra Prasad Mahato [13] proposed a optimal hybrid approach to solve this problem using the combination of cuckoo optimization search and ant colony optimization algorithms. In the proposed approach the clusters of resources were generated based on their loads to generate an optimal transactions schedule and cuckoo search Algorithm was used to generate the clusters.

Chunguang Zhang [14] proposed a cuckoo optimization search algorithm based on adaptive Cauchy mutation.In order to provide optimal quality of service in Internet of Things, the improved cuckoo search algorithm was used for hierarchical resource scheduling.

Tran-Ngoca [15] proposed an approach which was based on flexible combination of Cuckoo Search and Artificial Neural Network for detection of damage in bridges and beam like Structure. In proposed method, Cuckoo search was used for improving Artificial Neural Network training parameters such as bias and weight.

Cuckoo Search algorithm can be used along with Machine Learning Algorithm for better prediction. Sweta Kumari [17] proposed a model for improving the prediction accuracy of the required effort in Software development which was based on Artificial Neural Network and Cuckoo Search Algorithm.

The Social media such as Twitter, Facebook and Google plus etc. have changed the way of online communication. These Social media has become important platform of sharing and representing the sentiment of people, due to this there is need of effective and optimal sentiment analyses using data mining. Avinash Chandra Pandey [19] proposed a method of sentimental analysis on the data set of the social media called Twitter using a meta heuristic hybrid approach using cuckoo search and K-means Algorithms.

Effective an accurate Electric load forecasting is one of the most important part of power system. Xiaobo Zhanga 20] developed a satisfied and reliable method for load forecasting of electric by integrating singular spectrum analysis, support vector 
machine and Cuckoo search algorithms.

Sarangthem Sanajaoba 21] proposed an approach using Cuckoo Search Algorithm for optimal sizing of schemes such as Wind Battery, Photovoltaic Battery and Photovoltaic Wind Battery system of renewable energy system which are applicable in remote areas also.

Voltage stability enhancement and Reduction power loss is one of the essential requirement in Distribution networks. Thuan Thanh Nguyen [22] proposed a method to optimize this problem based on Cuckoo Search algorithm for optimally reconfiguration of network and allocation of distributed generation in distributed networks.

In the field of medical, machine learning algorithms are widely used for detection and prediction of diagnosis. However to make machine model more accurate and more accurate P. Mohapatra et al. [23] proposed a approach based on extreme learning machine and improved cuckoo search algorithms.

Due to environment problems and energy crisis. So now a days, it is very essential to find alternative of traditional energy resources. Solar energy is one the alternative, which has widely attracted the attention of researcher now a days. Jianzhou Wang et al. 24] proposed a hybrid model fro solar radiation forecasting based on Cuckoo Search algorithm and Extreme Learning Machine.

Image segmentation is quite popular now a days, it is used to select the meaningful objects. A segmentation extract the proper value of threshold to optimize the criterion using entropy. Ashish K Bhandari et. al. [25] proposed an approach for multilevel thresholding of satellite image segmentation based on wind driven optimization and cuckoo search algorithm.

Aziz Ouaarab et. al. [26] in 2014 proposed a discrete and extended version of basic cuckoo optimization search algorithm to solve Travelling salesman problem.

Yildiz et. al. [27] presented cuckoo search and implemented it successfully in milling operation for selection of machining parameter optimally.

Optimization of system reliability plays an very essential role in different real world application. Ehsan Valian et. al. [28] in 2013 proposed an improved and extended approach of cuckoo search for the optimization of reliability problems to solve engineering problems.

To provide the efficient and optimal fuel efficiency and to reduce cost of vehicle design, Ismail Durgun et. al. [29] in 2012 proposed a optimization model based on Cuckoo Search Algorithm, which is able to find better structural design of Vehicle Components.

Amira Gherboudj et. al. [30] in 2012 propose a discrete version of cuckoo search for dealing with binary optimisation problems.

Under complex nonlinear constraints in engineering many design problems are 
typically multiobjective. In order to solve multi objective problem of design optimization, Xin-She Yang et. al. [3] proposed a multiobjective cuckoo search in 2011.

S. Walton et. al. [4] presented a modified cuckoo search algorithm in 2011 and it observed that modified cuckoo search algorithm outperformed basic cuckoo search algorithm.

In 2010, Kutzelnigg et. al. [2] presented the detailed analysis of Cuckoo Hashing and indicated some drawbacks and benefits also.

For solving optimization problems a metaheuristic algorithm, called Cuckoo Search was Proposed and formulated by Xin-She Yang and Suash Deb [1] in 2009. This algorithm is based on the obligate brood parasitic behaviour of some cuckoo species in combination with the Levy flight behaviour of some birds and fruit flies. 


\begin{tabular}{|c|c|c|c|c|c|}
\hline S.No. & Authors & Year & Domain & Application & Proposed Work \\
\hline 1 & $\begin{array}{l}\text { Xingjuan } \\
\text { Cai et. al. } \\
{[7}\end{array}$ & 2019 & $\begin{array}{l}\text { Machine } \\
\text { Learning }\end{array}$ & $\begin{array}{l}\text { Software } \\
\text { defect predic- } \\
\text { tion. }\end{array}$ & $\begin{array}{l}\text { An optimized method for } \\
\text { Software defect prediction is } \\
\text { proposed, in which a hybrid } \\
\text { multi-objective cuckoo search } \\
\text { is used for optimized param- } \\
\text { eter selection of Support Vec- } \\
\text { tor Machine model. }\end{array}$ \\
\hline 2 & $\begin{array}{l}\text { Abubakar } \\
\text { Bala et. } \\
\text { al. } 8 \text { ] }\end{array}$ & 2019 & $\begin{array}{l}\text { Artificial in- } \\
\text { telligence }\end{array}$ & $\begin{array}{l}\text { Predict fail- } \\
\text { ures in turbo- } \\
\text { fan engines }\end{array}$ & $\begin{array}{l}\text { The cuckoo optimization } \\
\text { search algorithm is used to } \\
\text { choose right parameters and } \\
\text { topology for the echo state } \\
\text { network. }\end{array}$ \\
\hline 3 & $\begin{array}{l}\text { Prem Ja- } \\
\text { cob et. al. } \\
{[9}\end{array}$ & 2019 & $\begin{array}{l}\text { Cloud Com- } \\
\text { puting }\end{array}$ & $\begin{array}{l}\text { Optimal Task } \\
\text { Scheduling }\end{array}$ & $\begin{array}{l}\text { A hybrid approach was pro- } \\
\text { posed by combining the Par- } \\
\text { ticle swarm optimization and } \\
\text { Cuckoo search algorithm to } \\
\text { improve and optimize the } \\
\text { scheduling performance and } \\
\text { to reduced the cost fac- } \\
\text { tors as user cost and perfor- } \\
\text { mance cost in cloud comput- } \\
\text { ing scheduling tasks. }\end{array}$ \\
\hline 4 & $\begin{array}{l}\text { Liang } \\
\text { Chen et. } \\
\text { al. [10] }\end{array}$ & 2019 & $\begin{array}{l}\text { Meta- } \\
\text { heuristic } \\
\text { Search }\end{array}$ & $\begin{array}{l}\text { Dimension by } \\
\text { dimension en- } \\
\text { hancement }\end{array}$ & $\begin{array}{l}\text { Proposed a cuckoo search al- } \\
\text { gorithm to solve multi di- } \\
\text { mension optimization prob- } \\
\text { lem and enhance its perfor- } \\
\text { mance. }\end{array}$ \\
\hline 5 & $\begin{array}{l}\text { Tejeswara } \\
\text { Rao et. } \\
\text { al. } 11 \text {. }\end{array}$ & 2019 & Fuzzy Logic & $\begin{array}{l}\text { Power loss } \\
\text { minimization }\end{array}$ & $\begin{array}{l}\text { Proposed an method for } \\
\text { transmission losses reduc- } \\
\text { tion using multi-objective } \\
\text { cuckoo optimization search } \\
\text { algorithm. }\end{array}$ \\
\hline 6 & $\begin{array}{l}\text { Zhihua } \\
\text { Cui et. } \\
\text { al.[12] }\end{array}$ & 2019 & $\begin{array}{l}\text { Meta- } \\
\text { heuristic } \\
\text { search }\end{array}$ & $\begin{array}{ll}\text { Many ob- } \\
\text { jective op- } \\
\text { timization } \\
\text { search }\end{array}$ & $\begin{array}{l}\text { Proposed a hybrid many } \\
\text { objective search based on } \\
\text { cuckoo search algorithm. }\end{array}$ \\
\hline
\end{tabular}

Table 1: Cuckoo search in the last decade 


\begin{tabular}{|c|c|c|c|c|c|}
\hline S.No. & Authors & Year & Domain & Application & Proposed Work \\
\hline 7 & $\begin{array}{l}\text { Dharmendr: } \\
\text { Prasad } \\
\text { Mahato et. } \\
\text { al. 13 }\end{array}$ & 2019 & $\begin{array}{l}\text { Grid Com- } \\
\text { puting }\end{array}$ & $\begin{array}{l}\text { Transactions } \\
\text { Scheduling }\end{array}$ & $\begin{array}{l}\text { Proposed an optimize hybrid } \\
\text { approach with the combina- } \\
\text { tion of ant colony optimiza- } \\
\text { tion and cuckoo search. }\end{array}$ \\
\hline 8 & $\begin{array}{l}\text { Chunguang } \\
\text { Zhang et. } \\
\text { al. 114 }\end{array}$ & 2019 & $\begin{array}{l}\text { Internet of } \\
\text { Things }\end{array}$ & $\begin{array}{l}\text { Resource } \\
\text { Scheduling }\end{array}$ & $\begin{array}{l}\text { Cuckoo optimization search } \\
\text { algorithm was proposed } \\
\text { based on adaptive Cauchy } \\
\text { mutation and this improved } \\
\text { cuckoo search is used in Inter- } \\
\text { net of Thing for hierarchical } \\
\text { resource scheduling. }\end{array}$ \\
\hline 9 & $\begin{array}{l}\text { H. Tran- } \\
\text { Ngoca et. } \\
\text { al. [15] }\end{array}$ & 2019 & $\begin{array}{l}\text { Artificial In- } \\
\text { telligence }\end{array}$ & $\begin{array}{l}\text { damage detec- } \\
\text { tion }\end{array}$ & $\begin{array}{l}\text { A flexible combination of } \\
\text { Cuckoo Search and Artificial } \\
\text { Neural Network was proposed } \\
\text { to improve Artificial Neural } \\
\text { Network Parameters such as } \\
\text { bias and weight. }\end{array}$ \\
\hline 10 & $\begin{array}{l}\text { Maoqing } \\
\text { Zhang et. } \\
\text { al. [16] }\end{array}$ & 2018 & Local search & $\begin{array}{l}\text { Multi objec- } \\
\text { tive optimiza- } \\
\text { tion }\end{array}$ & $\begin{array}{l}\text { Hybrid } \\
\text { Search is proposed using } \\
\text { cuckoo search algorithm to } \\
\text { enhance the local search } \\
\text { ability. }\end{array}$ \\
\hline 11 & $\begin{array}{l}\text { Sweta } \\
\text { Kumari et. } \\
\text { al. [17 }\end{array}$ & 2018 & $\begin{array}{l}\text { Machine } \\
\text { Learning }\end{array}$ & $\begin{array}{l}\text { Software de- } \\
\text { velopment } \\
\text { effort predic- } \\
\text { tion }\end{array}$ & $\begin{array}{l}\text { Proposed an approach for } \\
\text { better estimation of Software } \\
\text { development effort and its } \\
\text { prediction based on Cuckoo } \\
\text { search algorithm and Artifi- } \\
\text { cial Neural Network. }\end{array}$ \\
\hline 12 & $\begin{array}{l}\text { Xiaohua } \\
\text { Zhu et. al. } \\
\text { 18 }\end{array}$ & 2018 & $\begin{array}{l}\text { fluid cat- } \\
\text { alytic }\end{array}$ & $\begin{array}{l}\text { Improve the } \\
\text { population } \\
\text { diversity }\end{array}$ & $\begin{array}{l}\text { Proposed an approach to de- } \\
\text { sign new RNA crossover op- } \\
\text { erator to improve the popula- } \\
\text { tion diversity based on cuckoo } \\
\text { search algorithm. }\end{array}$ \\
\hline
\end{tabular}

Table 2: Cuckoo search in the last decade (continue..) 


\begin{tabular}{|c|c|c|c|c|c|}
\hline S.No. & Authors & Year & Domain & Application & Proposed Work \\
\hline 13 & $\begin{array}{l}\text { Avinash } \\
\text { Chandra } \\
\text { Pandey et. } \\
\text { al. 19. }\end{array}$ & 2017 & $\begin{array}{l}\text { Social Me- } \\
\text { dia }\end{array}$ & $\begin{array}{l}\text { Sentiment } \\
\text { analysis }\end{array}$ & $\begin{array}{l}\text { Proposed an approach for the } \\
\text { analysis of Twitter sentiment } \\
\text { using flexible combination of } \\
\text { cuckoo search and K-means } \\
\text { algorithm. }\end{array}$ \\
\hline 14 & $\begin{array}{l}\text { Xiaobo } \\
\text { Zhanga et. } \\
\text { al. } 20 \text {. }\end{array}$ & 2017 & $\begin{array}{l}\text { Machine } \\
\text { Learning }\end{array}$ & $\begin{array}{l}\text { Electric load } \\
\text { forecasting }\end{array}$ & $\begin{array}{l}\text { Proposed a novel model for } \\
\text { electric load forecasting us- } \\
\text { ing a hybrid approach with } \\
\text { singular spectrum analysis, } \\
\text { support vector machine and } \\
\text { Cuckoo search algorithms. }\end{array}$ \\
\hline 15 & $\begin{array}{l}\text { Sarangthem } \\
\text { Sanajaoba } \\
\text { et. al. } 21\end{array}$ & 2016 & $\begin{array}{l}\text { Renewable } \\
\text { energy }\end{array}$ & $\begin{array}{l}\text { Optimal } \\
\text { sizing }\end{array}$ & $\begin{array}{l}\text { Applied Cuckoo Search Algo- } \\
\text { rithm for optimal sizing. }\end{array}$ \\
\hline 16 & $\begin{array}{l}\text { Thuan } \\
\text { Thanh } \\
\text { Nguyen et. } \\
\text { al. 222 }\end{array}$ & 2016 & $\begin{array}{l}\text { Distribution } \\
\text { network }\end{array}$ & $\begin{array}{l}\text { Optimal net- } \\
\text { work reconfig- } \\
\text { uration }\end{array}$ & $\begin{array}{l}\text { Proposed a methodology to } \\
\text { optimize topology of net- } \\
\text { work and distributed genera- } \\
\text { tion placement in distribution } \\
\text { network using cuckoo search } \\
\text { algorithm. }\end{array}$ \\
\hline 17 & $\begin{array}{l}\text { P. Mohap- } \\
\text { atra et. al. } \\
{[23}\end{array}$ & 2015 & $\begin{array}{l}\text { Machine } \\
\text { Learning }\end{array}$ & $\begin{array}{l}\text { Medical data } \\
\text { classification }\end{array}$ & $\begin{array}{l}\text { Proposed an algorithm for } \\
\text { classification of medical data } \\
\text { based on improved cuckoo } \\
\text { search and machine learning } \\
\text { algorithm. }\end{array}$ \\
\hline 18 & \begin{tabular}{l}
\multicolumn{2}{c}{ Jianzhou } \\
Wang et. \\
al. 24
\end{tabular} & 2015 & Energy & $\begin{array}{l}\text { Solar radia- } \\
\text { tion forecast- } \\
\text { ing }\end{array}$ & $\begin{array}{l}\text { Proposed hybrid model based } \\
\text { on Cuckoo search algorithm } \\
\text { for solar radiation forecast- } \\
\text { ing. }\end{array}$ \\
\hline 19 & $\begin{array}{l}\text { Ashish K } \\
\text { Bhandari } \\
\text { et. al. } 25\end{array}$ & 2014 & $\begin{array}{l}\text { Image seg- } \\
\text { mentation }\end{array}$ & $\begin{array}{l}\text { Multilevel } \\
\text { thresholding }\end{array}$ & $\begin{array}{l}\text { Proposed an approach for } \\
\text { multilevel thresholding of } \\
\text { satellite image segmentation } \\
\text { based on wind driven opti- } \\
\text { mization and cuckoo search } \\
\text { algorithm. }\end{array}$ \\
\hline
\end{tabular}

Table 3: Cuckoo search in the last decade (continue..) 


\begin{tabular}{|c|c|c|c|c|c|}
\hline S.No. & Authors & Year & Domain & Application & Proposed Work \\
\hline 20 & $\begin{array}{l}\text { Aziz } \\
\text { Ouaarab } \\
\text { et. al. [26] }\end{array}$ & 2014 & $\begin{array}{l}\text { Combinatorial } \\
\text { optimisation }\end{array}$ & $\begin{array}{l}\text { Traveling } \\
\text { salesman } \\
\text { problem }\end{array}$ & $\begin{array}{l}\text { Proposed a discrete and im- } \\
\text { proved version of cuckoo op- } \\
\text { timization search algorithm } \\
\text { to solve Travelling salesman } \\
\text { problem. }\end{array}$ \\
\hline 21 & $\begin{array}{ll}\text { Ali } & \text { R. } \\
\text { Yildiz } & \text { et. } \\
\text { al. } 27] & \end{array}$ & 2013 & $\begin{array}{l}\text { Milling op- } \\
\text { erations }\end{array}$ & $\begin{array}{l}\text { Optimal } \\
\text { machining } \\
\text { parameters }\end{array}$ & $\begin{array}{l}\text { Proposed a model for selec- } \\
\text { tion of machining parameter } \\
\text { optimally using cuckoo search } \\
\text { algorithm. }\end{array}$ \\
\hline 22 & $\begin{array}{l}\text { Ehsan } \\
\text { Valian et. } \\
\text { al. } 28\end{array}$ & 2013 & $\begin{array}{l}\text { Meta- } \\
\text { heuristic }\end{array}$ & $\begin{array}{l}\text { Reliability } \\
\text { problem }\end{array}$ & $\begin{array}{l}\text { Proposed an extended cuckoo } \\
\text { search for the optimization of } \\
\text { reliability problems. }\end{array}$ \\
\hline 23 & $\begin{array}{l}\text { Ismail } \\
\text { Durgun et. } \\
\text { al. } 29 \text {. }\end{array}$ & 2012 & $\begin{array}{l}\text { Vehicle } \\
\text { Components }\end{array}$ & $\begin{array}{l}\text { Structural De- } \\
\text { sign }\end{array}$ & $\begin{array}{l}\text { Proposed a method to solve } \\
\text { the optimization problems of } \\
\text { structural design based on } \\
\text { cuckoo optimization search } \\
\text { algorithm. }\end{array}$ \\
\hline 24 & $\begin{array}{l}\text { Amira } \\
\text { Gherboudj } \\
\text { et. al. } 30\end{array}$ & 2012 & $\begin{array}{l}\text { Meta- } \\
\text { heuristics }\end{array}$ & $\begin{array}{l}\text { Knapsack } \\
\text { problems }\end{array}$ & $\begin{array}{l}\text { proposed a discrete binary } \\
\text { cuckoo search to solve } 0-1 \\
\text { knapsack problems. }\end{array}$ \\
\hline 25 & $\begin{array}{l}\text { Xin-She } \\
\text { Yang et. } \\
\text { al. } 3 \text {. }\end{array}$ & 2011 & $\begin{array}{l}\text { Multi ob- } \\
\text { jective } \\
\text { problems }\end{array}$ & $\begin{array}{l}\text { Design opti- } \\
\text { mization }\end{array}$ & $\begin{array}{l}\text { In order to solve multi objec- } \\
\text { tive problem of design opti- } \\
\text { mization, Proposed a multi- } \\
\text { objective cuckoo search. }\end{array}$ \\
\hline 26 & $\begin{array}{l}\text { S. Walton } \\
\text { et. al. [4] }\end{array}$ & 2011 & $\begin{array}{l}\text { Meta- } \\
\text { heuristic }\end{array}$ & $\begin{array}{l}\text { Optimisation } \\
\text { algorithm }\end{array}$ & $\begin{array}{l}\text { Proposed a modified cuckoo } \\
\text { search algorithm and it had } \\
\text { been shown that modified } \\
\text { cuckoo search algorithm per- } \\
\text { formed better than basic } \\
\text { cuckoo search algorithm. }\end{array}$ \\
\hline 26 & $\begin{array}{l}\text { Kutzelnigg } \\
\text { et. al. [2] }\end{array}$ & 2010 & $\begin{array}{l}\text { Meta- } \\
\text { heuristic }\end{array}$ & $\begin{array}{l}\text { Cuckoo Hash- } \\
\text { ing }\end{array}$ & $\begin{array}{l}\text { Presented the analysis of } \\
\text { Cuckoo Hashing with Ran- } \\
\text { dom Graphs and a Stash. }\end{array}$ \\
\hline 26 & $\begin{array}{l}\text { S. Xin-She } \\
\text { Yang and } \\
\text { Suash Deb } \\
11\end{array}$ & 2009 & $\begin{array}{l}\text { Meta- } \\
\text { heuristic }\end{array}$ & $\begin{array}{l}\text { Cuckoo } \\
\text { Search }\end{array}$ & $\begin{array}{l}\text { Proposed and formulated } \\
\text { metaheuristic algorithm, } \\
\text { called Cuckoo Search for } \\
\text { solving optimization prob- } \\
\text { lems }\end{array}$ \\
\hline
\end{tabular}

Table 4: Cuckoo search in the last decade (continue..) 


\section{Conclusion}

In this brief survey, a relatively comprehensive bibliography regarding cuckoo search algorithm has been summarised. References have been sorted systematically into proper categories. The speedily expanding literature implies that cuckoo search algorithm is a very recent, active and hot research field in the area of optimization such as Data fusion in wireless sensor networks, Engineering optimization problems, Neural network training, Manufacturing scheduling and NP-hard combinatorial optimization problems etc. Therefore, There is no doubt that more publication and studies on cuckoo search will appear in the near future.

\section{References}

[1] X. Yang and S. Deb, "Cuckoo Search via Levy Flights", World Congress on Nature \& Biologically Inspired Computing, pp. 210-214, 2009.

[2] Kutzelnigg and Reinhard, "A further analysis of Cuckoo Hashing with a Stash and Random Graphs of Excess r", DISCRETE MATHEMATICS AND THEORETICAL COMPUTER SCIENCE, Vol. 12, pp 81-101, 2010.

[3] X. Yang and S. Deb, "Multiobjective cuckoo search for design optimization" Computers and Operations Research, no. 2009, pp. 1-9, 2011.

[4] S. Walton, O. Hassan, K. Morgan, and M. R. Brown, "Modified cuckoo search: A new gradient free optimisation algorithm," Interdiscip. J. Nonlinear Sci. Nonequilibrium Complex Phenom., vol. 44, no. 9, pp. 710-718, 2011.

[5] X. Yang, "Cuckoo Search and Firefly Algorithm: Overview and Analysis", Springer International Publishing Switzerland, pp. 1-26, 2014.

[6] A. B. Mohamad, A. M. Zain, N. Erne, and N. Bazin, "Cuckoo Search Algorithm for Optimization Problems - A Literature Review and its Applications," Appl. Artif. Intell., vol. 28, no. 5, pp. 419-448, 2014.

[7] X. Cai, Y. Niu, S. Geng, J. Li, J. Chen, and J. Zhang, "An under-sampled software defect prediction method based on hybrid multi-objective cuckoo search," no. May, pp. 1-14, 2019.

[8] A. Bala, I. Ismail, R. Ibrahim, S. M. Sait, and H. Onoruoiza, "Prediction Using Cuckoo Search Optimized Echo State Network" Arab. J. Sci. Eng., vol. 44, no. 11, pp. 9769-9778, 2019. 
[9] T. Prem Jacob and K. Pradeep, "A Multi - objective Optimal Task Scheduling in Cloud Environment Using Cuckoo Particle Swarm Optimization," Wirel. Pers. Commun., vol. 109, no. 1, pp. 315-331, 2019.

[10] L. Chen, L. Chen, and L. Chen, "Dimension-by-dimension enhanced cuckoo search algorithm for global optimization" Soft Comput., vol. 23, no. 21, pp. 11297-11312, 2019.

[11] T. Rao, N. Mani, S. Matta, S. Koratana, and R. Kumar, "A fuzzified Pareto multiobjective cuckoo search algorithm for power losses minimization incorporating SVC," Soft Comput., vol. 23, no. 21, pp. 10811-10820, 2019.

[12] Z. Cui, M. Zhang, H. Wang, X. Cai, W. Zhang, and H. Wang, "A hybrid many-objective cuckoo search algorithm" Soft Comput., vol. 23, no. 21, pp. 10681-10697, 2019.

[13] D. P. Mahato, "On scheduling transaction in grid computing using cuckoo search-ant colony optimization considering load" Cluster Comput., vol. 0123456789, 2019.

[14] C. Zhang, G. Zeng, H. Wang, and X. Tu, "Hierarchical resource scheduling method using improved cuckoo search algorithm for internet of things" pp. 16061614, 2019.

[15] H. Tran-ngoc, S. Khatir, G. De Roeck, T. Bui-tien, and M. A. Wahab, "An efficient artificial neural network for damage detection in bridges and beam-like structures by improving training parameters using cuckoo search algorithm" Eng. Struct., vol. 199, no. September, p. 109637, 2019

[16] M. Zhang, H. Wang, Z. Cui, and J. Chen, "Hybrid multi-objective cuckoo search with dynamical local search," Memetic Comput., vol. 10, no. 2, pp. 199-208, 2018.

[17] S. Kumari and S. Pushkar, "Cuckoo search based hybrid models for improving the accuracy of software effort estimation," Microsyst. Technol, vol. 24, no. 12, pp. 4767-4774, 2018.

[18] X. Zhu and N. Wang, "Splicing process inspired cuckoo search algorithm based ENNs for modeling FCCU reactor-regenerator system" Chemical Engineering Journal, 2018. 
[19] A. C. Pandey, D. S. Rajpoot, and M. Saraswat, "Twitter sentiment analysis using hybrid cuckoo search method," vol. 53, pp. 764-779, 2017.

[20] X. Zhang, J. Wang, and K. Zhang, "Short-term electric load forecasting based on singular spectrum analysis and support vector machine optimized by Cuckoo search algorithm" Electr. Power Syst. Res., vol. 146, pp. 270-285, 2017.

[21] S. Sanajaoba and E. Fernandez, "Maiden application of Cuckoo Search algorithm for optimal sizing of a remote hybrid renewable energy System," Renew. Energy, vol. 96, pp. 1-10, 2016.

[22] T. Thanh, A. Viet, and T. Anh, "Electrical Power and Energy Systems A novel method based on adaptive cuckoo search for optimal network reconfiguration and distributed generation allocation in distribution network," Int. J. Electr. POWER ENERGY Syst., vol. 78, pp. 801-815, 2016.

[23] P. Mohapatra, S. Chakravarty, and P. K. Dash, "An improved cuckoo search based extreme learning machine for medical data classification," Swarm Evol. Comput., vol. 24, pp. 25-49, 2015.

[24] J. Wang, H. Jiang, Y. Wu, and Y. Dong, "Forecasting solar radiation using an optimized hybrid model by Cuckoo Search algorithm," Energy, vol. 81, pp. 627-644, 2015.

[25] A. Kumar, V. Kumar, A. Kumar, and G. Kumar, "Cuckoo search algorithm and wind driven optimization based study of satellite image segmentation for multilevel thresholding using Kapur' s entropy," Expert Syst. Appl., vol. 41, no. 7, pp. 3538-3560, 2014.

[26] A. Ouaarab, B. Ahiod and X. Yang, "Discrete cuckoo search algorithm for the travelling salesman problem," pp. 1659-1669, 2014.

[27] Ali R. Yildiz, "Cuckoo search algorithm for the selection of optimal machining parameters in milling operations" pp. 55-61, 2013.

[28] E. Valian, S. Tavakoli, S. Mohanna, and A. Haghi, "Computers and Industrial Engineering Improved cuckoo search for reliability optimization problems" Comput. Ind. Eng., vol. 64, no. 1, pp. 459-468, 2013.

[29] I. Durgun and Ali R. Yildiz, "Structural Design Optimization of Vehicle Components Using Cuckoo Search Algorithm", CARL HANSER VERLAG MUNICH, GERMANY, Vol. 54, pp 185-188, 2012. 
[30] A. Gherboudj; A. Layeb and Salim Chikhi, "Solving 0-1 knapsack problems by a discrete binary version of cuckoo search algorithm", International Journal of Bio-Inspired Computation (IJBIC), Vol. 4, No. 4, 2012. 